\title{
Correction to: Measuring persistent and transient energy efficiency in the US
}

\author{
Massimo Filippini • Lester C. Hunt
}

Published online: 24 October 2017

(C) Springer Science+Business Media B.V. 2017

\section{Correction to: Energy Efficiency https://doi.org/10.1007/s12053-015- \\ 9388-5}

The article "Measuring persistent and transient energy efficiency in the US," written by Massimo Filippini and Lester C. Hunt was originally published Online First without open access. After publication in volume 9 , issue 3, page 663-675, the author decided to opt for Open Choice and to make the article an open access publication. Therefore, the copyright of the article has been changed to (C) The Author(s) 2015, and the article is forthwith distributed under the terms of the Creative Commons Attribution 4.0 International License (http://creativecommons.org/licenses/by/4.0/), which permits use, duplication, adaptation, distribution, and reproduction in any medium or format, as long as you give appropriate credit to the original author(s) and the source, provide a link to the Creative Commons license, and indicate if changes were made.

\footnotetext{
M. Filippini

Center for Energy Policy and Economics, ETH Zürich, Zürich,

Switzerland

e-mail: MFilippini@ethz.ch

M. Filippini

e-mail: Massimo.Filippini@usi.ch

M. Filippini

Department of Economics, Università della Svizzera Italiana,

Lugano, Switzerland

L. C. Hunt $(\bowtie)$

Surrey Energy Economics Centre (SEEC), University of Surrey,

Surrey, England, UK

e-mail: L.Hunt@surrey.ac.uk

e-mail: Lester.Hunt@kapsarc.org

L. C. Hunt

King Abdullah Petroleum Studies and Research Center

(KAPSARC), Riyadh, Saudi Arabia
} 